\title{
Response of Phosphate Solubilising Inoculants (Jumpstart) on Biochemistry and Yield of Rice (Oryza sativa $L$.)
}

\author{
M. Geethalakshmi ${ }^{1}$, V. Ravichandran ${ }^{1 *}$, P. Boominathan ${ }^{2}$ and P. Jeyakumar ${ }^{2}$ \\ ${ }^{1}$ Department of Rice, Tamil Nadu Agricultural University, Coimbatore-641003, \\ Tamil Nadu, India \\ ${ }^{2}$ Department of Crop Physiology, Tamil Nadu Agricultural University, Coimbatore-641003, \\ Tamil Nadu, India \\ *Corresponding author
}

\section{A B S T R A C T}

Phosphorus plays a significant role in several physiological and biochemical activities in plants. Phosphorus in soils is immobilized due to formation of insoluble complexes such as iron and aluminium hydrous oxides and calcium carbonate. Phosphate-solubilizing microorganisms (PSM) play an important role in insoluble phosphates into soluble forms involves processes of acidulation, ion chelation and exchange reactions. Present study, a field experiment was carried out to study the physiological and yield response of phosphate solubilising inoculants (JumpStart) on rice variety CO 47 under machine transplanting rice ecosystem. The present study revealed that the treatment $\mathrm{P}_{3} \mathrm{~S}_{3}(100 \% \mathrm{P}+$ JumpStart 10E5) was recorded increased total chlorophyll $\left(3.03 \mathrm{mg} \mathrm{g}^{-1}\right)$ and higher leaf carbohydrate $\left(82.06 \mathrm{mg} \mathrm{g}^{-1}\right)$ at $50 \%$ flowering stage. The lower enzyme activity of acid phosphatase $\left(0.022 \mu \mathrm{mol}\right.$ of pNPP g $\left.\mathrm{gin}^{-1}\right)$ and ATPase $\left(29.37 \mu \mathrm{g}\right.$ of $\left.\mathrm{Pi} \mathrm{g}^{-1} \mathrm{~h}^{-1}\right)$ were recorded by treatment $\mathrm{P}_{3} \mathrm{~S}_{3}(100 \% \mathrm{P}+$ JumpStart 10E5) over control at 50\% flowering stage. The uptake of phosphorus by plants was found higher in $\mathrm{P}_{3} \mathrm{~S}_{3}$ treatment observed at all stages of crop growth. At $50 \%$ flowering stage, phosphorus $\left(69.26 \mathrm{~kg} \mathrm{ha}^{-1}\right)$, uptake were observed higher in $\mathrm{P}_{3} \mathrm{~S}_{3}$ treatment than control. The maximum grain yield of $8426 \mathrm{~kg}$ ha $^{-1}$ was registered by $\mathrm{P}_{3} \mathrm{~S}_{3}(100 \% \mathrm{P}+$ JumpStart $)$ with an increase of 16.4 per cent over control. This might be due to the significant increment of major yield components such as number of productive tillers per plant, panicle dry weight and number of grains per panicle by the application of $100 \%$ recommended phosphorus with seed treatment of JumpStart $10 \mathrm{E} 5$.

\section{Introduction}

Phosphorus is an essential nutrient required by rice (Kim et al., 1998) and it has a defined role in plant metabolisms such as root development, photosynthesis, nutrient transport within the plant, Meiosis, phospholipid in cell walls and reproductive parts of plant (Rasipour and Asgharzadeh, 2007). The judicious and proper use of phosphorous in rice markedly increases the yield and quality of rice. Without adequate supply of plant with phosphorous, plant cannot attain its maximum yield.

Low level of available $\mathrm{P}$ in soils is one of the major constraints for rice production in the world. This is particularly apparent under 
upland conditions commonly characterized by poorly fertile, erodible, badly leached, highly acidic, and P-fixing soils, normally with little or no fertilizer applied (IRRI, 1997). Even under lowland conditions, $\mathrm{P}$ deficiency is identified as a main factor limiting the performance of modern rice varieties to approach their optimum yields. Application of $\mathrm{P}$ fertilizers is a quick remedy for $\mathrm{P}$ deficiency in rice soils. However, nonorganic fertilizers are not always available to a large sector of poor rice farmers. Besides, some rice soils that are low in available $\mathrm{P}$ can also fix it into a highly less soluble mineral. Dobermann et al., (1998) estimated that more than $90 \%$ of the added fertilizer $\mathrm{P}$ may rapidly be transformed to $\mathrm{P}$ forms that are not easily available to plants.

The microorganisms perform an important role in agriculture by supplying nutrients to plants and reduce the demand of chemical fertilizers (Cakmakci et al., 2006). Particularly, phosphate solubilizing microorganisms are able to solubilize unavailable soil $\mathrm{P}$ and enhance the yield of crops (Adesemoye and Kloepper, 2009). Phosphate solubilizing microorganisms (PSMs) are ubiquitous, and their numbers vary from soil to soil.

The use of $\mathrm{P}$ solubilizing microorganisms improves the soil fertility and increase the crop production to fulfill the requirement. Further, the efficiency of these microorganisms to meet $\mathrm{P}$ requirement of crops will depend greatly on their impact under practical farming conditions. Penicillium bilaii (a phosphorus solubilising fungus) is a newly isolated soil fungus that has profound effect on solubilization of phosphorus. The efficacy of Penicillium bilaii has been test verified in various crops such as wheat, canola, chick pea, mustard and lentil elsewhere. However, the usefulness of Penicillium bilaii has not been tested in rice crop under machine transplanting system.

Keeping this in view, the present study was conducted at field level to evaluate the performance of different inoculation of Penicillium bilaii in combination with three levels of phosphatic fertilizer on biochemistry, $\mathrm{P}$ uptake and yield of rice.

\section{Materials and Methods}

The Present investigation was carried out in the field no. H7a of Department of Rice, Tamil Nadu Agricultural University, Coimbatore during Kharif season of 2015. Rice variety $\mathrm{CO} 47$ seed material collected from Department of Rice. Before sowing, three bags (1 kg each) of rice seeds were soaked for 24 hours. Seeds were then seed treated with three different population of Phosphate solubilising inoculants Penicillium bilaii (Jump Start) at the rate of $160 \mathrm{mg}$ per $\mathrm{Kg}$ of seeds and $6 \mathrm{ml}$ of water was added and agitated for one minute as per the treatments and compared with the recommended seed treatment of Azophos at the rate of $20 \mathrm{~g} \mathrm{~kg}^{-1}$ of seeds and control (No seed treatment).The experimental field with provisions made for draining excess water was well irrigated, puddled and leveled by leveler to minimize undulations, field conditions were maintained for two days to make the land convenient for machine transplanting.

The field experiment was laid out in split plot design with three replications. The treatments are as follows three main plot of three different P levels P1- $0 \%\left(0 \mathrm{kgP} \mathrm{ha}^{-1}\right), \mathrm{P} 2-50$ $\% \mathrm{P}\left(25 \mathrm{~kg} \mathrm{P} \mathrm{ha}^{-1}\right)$ and $\mathrm{P} 3-100 \% \mathrm{P}\left(50 \mathrm{kgP} \mathrm{ha}^{-}\right.$

$\left.{ }^{1}\right)$ (Recommended dose). Sub plot of five different seed treatments S1- No Seed Treatment, S2- JumpStart 10E4 (0.00967 mg $\mathrm{kg}^{-1}$ of seeds), S3-JumpStart 10E5 (0.0967 mg kg-1 of seeds), S4- JumpStart 10E6 (9.667 $\mathrm{mg} \mathrm{kg}$ of seeds) and S5- Azophos at the $20 \mathrm{~g}$ 
$\mathrm{kg}-1$ of seeds. Five plants were selected at different growth stages for recording observation. Total Chlorophyll content in leaves was estimated by using the method described by Hiscox and Israelstam (1979) and expressed in $\mathrm{mg} \mathrm{g}^{-1}$ fresh weight. The total carbohydrate content of the leaf and root samples were estimated by following the method suggested by Fales (1951) and all expressed in $\mathrm{mg} \mathrm{g}^{-1}$ on dry weight basis.

Acid phosphatase activity of the seedling roots were determined by the method of Hooley (1984).Chlorophyll content in leaves was estimated by using the method described by Hiscox and Israelstam (1979) and expressed in $\mathrm{mg} \mathrm{g}^{-1}$ fresh weight. Adenosine Triphosphatase activity of the rice root was determined by the method of Umbreit et al., (1964) and the enzyme activity was expressed as $\mu \mathrm{g}$ of $\mathrm{Pi} / \mathrm{g}$ fresh weight/hr

Uptake of phosphorus nutrients were calculated as the product of total dry matter production $\left(\mathrm{kg} \mathrm{ha}^{-1}\right)$ with the corresponding nutrient content of the plant parts at active tillering (AT), panicle initiation (PI), flowering $(\mathrm{F})$ and grain filling (GF) stage (Hartemink et al., 2000).

The yield and its components were recorded at harvest (Yoshida et al., 1972). The data collected were subjected to statistical analysis in split plot design by Gomez and Gomez (1984).

\section{Results and Discussion}

\section{Total chlorophyll}

Total chlorophyll content is an imperative indicator of crop growth. There was a general decrease in chlorophyll content observed from flowering to grain filling stage. Hence, measurement of chlorophyll indirectly explains the efficiency of the photosynthesis and photosynthate production. Total chlorophyll content was steadily increased up to $50 \%$ flowering stage $\left(3.03 \mathrm{mg} \mathrm{g}^{-1}\right)$ and thereafter it decreased at grain filling stage (2.13 $\left.\mathrm{mg} \mathrm{g}^{-1}\right)$ due to initiation of senescence phase (Table 1). During senescence, the total chlorophyll was altered due to shift in the macro nutrient concentration. The content of total chlorophyll content of leaf decreased due to deficiency of phosphorus in $0 \% \mathrm{P}$ with no seed treatment, which is $25 \%$ low when compared to $100 \% \mathrm{P}+$ JumpStart 10E5 at $50 \%$ flowering stage. The increase of chlorophyll content is due to enhanced absorption of irons from rhizosphere and increased translocation to the shoot without any chelation inside the root (Wang et al., 2009). Similar findings were reported by Mehrvarz and Chaichi (2008) that increase in chlorophyll content and photosynthesis rates with inoculation of PSB in aerobic rice.

\section{Total carbohydrate}

Total carbohydrate includes all those carbohydrates which can be used in the plant body as a source of energy or as building material. The determination of the total carbohydrate content is of greater significance than that of individual carbohydrates. In this study, increased amount of leaf carbohydrate was seen in $\mathrm{P}_{3} \mathrm{~S}_{3}(100 \% \mathrm{P}+$ JumpStart 10E4) during $50 \%$ flowering stage.

The control treatment, $\mathrm{P}_{1} \mathrm{~S}_{1}$ had only 52.04 $\mathrm{mg} \mathrm{g}^{-1}$ of leaf carbohydrate which is $57.69 \%$ lower than $\mathrm{P}_{3} \mathrm{~S}_{3}$ treatment (Table 2). This increase due to higher solubilizing ability of Penicillium bilaii combined with $100 \% \mathrm{P}$ application increased the availability of phosphorus in soil resulted in higher leaf carbohydrate content (Prasanna, 2013). Degroot et al., (2003) found a reduction in starch and soluble sugars with decreasing phosphorus application. Low phosphorus condition largely affects the carbohydrate 
content in tomato (Ramezan Ali Khavari, 2008).

\section{Acid phosphatase enzyme activity}

Acid phosphatase enzyme activity is responsible for $\mathrm{P}$ hydrolysis from organic compounds, favouring $\mathrm{P}$ mobilization and translocation. An increase in root phosphatase activity was often correlated with decrease in phosphorus level in root as well as leaf (Muthaiya, 2010). In this study, the treatment with $0 \% \mathrm{P}+\mathrm{No}$ seed treatment at $50 \%$ flowering stage recorded higher root acid phosphatase activity, which is $84.93 \%$ higher than $100 \% \mathrm{P}+$ JumpStart 10E5 $\left(\mathrm{P}_{3} \mathrm{~S}_{3}\right)$ (Table 3). Yun et al., (2001) found that the acid phosphatase enzyme secretion from roots enhanced protein release to acidify the rhizophere and mobilize phosphorus which improves the acquisition and reutilization, thus helping the plants to grow under $\mathrm{P}$ deficit conditions. Jeong Hyun Lim et al., (2003) reported that acid phosphatases (APases) play a role in the release of phosphate in organic complexes in soil.

\section{Adenosine triphosphatase activity \\ (ATPase)}

Light energy absorbed by chlorophyll is converted into stable chemical energy and drive ATP formation via ATPase in the chloroplasts. ATPase is the metabolic enzyme integral to ATP hydrolysis and ATP serve to transport chemical energy in cell to drive metabolism (Pederson and Carafoli, 1987). Root ATPase activity was greatly influenced by different $\mathrm{P}$ levels and Penicillium bilaii (a phosphorus solubilising fungus) in our study. The values were found to increase from active tillering stage to $50 \%$ flowering stage. However, the value was higher in $0 \% \mathrm{P}$ than at $50 \%$ and $100 \%$ P levels. At $50 \%$ flowering stage the ATPase activity at $0 \% \mathrm{P}$ was 57.48 and $48.9 \%$ higher in comparison with $100 \% \mathrm{P}$ levels (Table 4). Hong Shen et al., (2006) found that $\mathrm{P}$ starvation enhanced the activity of plasma membrane $\mathrm{H}^{+}$-ATPase in soybean roots.

Fig.1 Effect of P levels and Penicillium bilaii inoculants on grain yield (kg/ha) of rice

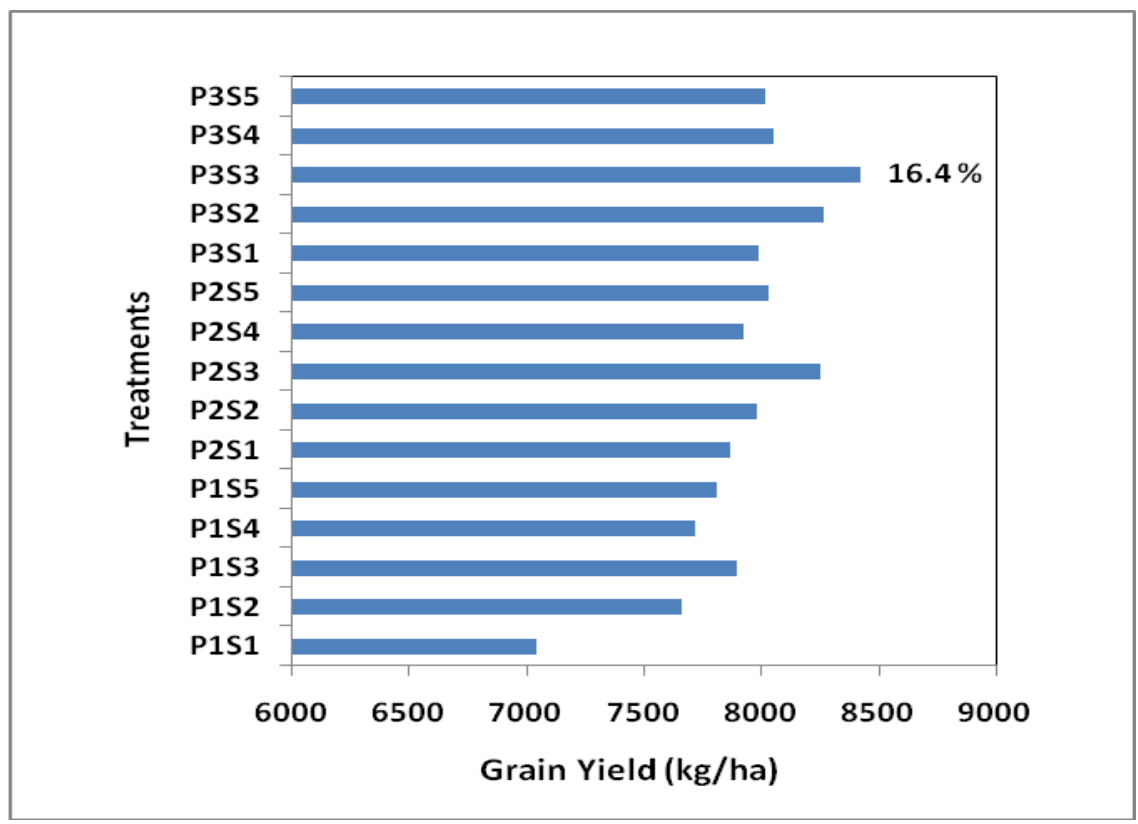


Table.1 Effect of P levels and Penicillium bilaii inoculants on total chlorophyll $\left(\mathrm{mg} \mathrm{g}^{-1}\right)$ at different growth stages of rice

\begin{tabular}{|c|c|c|c|c|c|}
\hline Treatments & $\begin{array}{c}\text { AT } \\
\text { (40 DAS) }\end{array}$ & $\begin{array}{c}\text { PI } \\
\text { (55 DAS) }\end{array}$ & $\begin{array}{c}\text { F } \\
(85 \text { DAS })\end{array}$ & $\begin{array}{c}\text { GF } \\
(105 \text { DAS })\end{array}$ & Mean \\
\hline $\mathbf{P}_{1} \mathbf{S}_{1}$ & 1.23 & 1.75 & 2.42 & 1.78 & 1.80 \\
\hline $\mathbf{P}_{1} \mathbf{S}_{2}$ & 1.38 & 2.06 & 2.64 & 1.87 & 1.99 \\
\hline $\mathbf{P}_{1} \mathbf{S}_{3}$ & 1.42 & 2.25 & 2.76 & 1.90 & 2.08 \\
\hline $\mathbf{P}_{1} \mathbf{S}_{4}$ & 1.36 & 1.91 & 2.58 & 1.85 & 1.93 \\
\hline $\mathbf{P}_{1} \mathbf{S}_{5}$ & 1.32 & 1.84 & 2.46 & 1.84 & 1.87 \\
\hline $\mathbf{P}_{2} \mathbf{S}_{1}$ & 1.35 & 1.87 & 2.51 & 1.83 & 1.89 \\
\hline $\mathbf{P}_{2} \mathbf{S}_{2}$ & 1.50 & 2.18 & 2.76 & 1.89 & 2.08 \\
\hline $\mathbf{P}_{2} \mathbf{S}_{3}$ & 1.58 & 2.39 & 2.87 & 1.95 & 2.20 \\
\hline $\mathbf{P}_{2} \mathbf{S}_{4}$ & 1.44 & 2.05 & 2.65 & 1.88 & 2.01 \\
\hline $\mathbf{P}_{2} \mathbf{S}_{5}$ & 1.40 & 1.94 & 2.58 & 1.86 & 1.95 \\
\hline $\mathbf{P}_{3} \mathbf{S}_{1}$ & 1.43 & 1.95 & 2.63 & 1.87 & 1.97 \\
\hline $\mathbf{P}_{3} \mathbf{S}_{2}$ & 1.62 & 2.31 & 2.85 & 2.03 & 2.20 \\
\hline $\mathbf{P}_{3} \mathbf{S}_{3}$ & 1.66 & 2.57 & 3.03 & 2.13 & 2.35 \\
\hline $\mathbf{P}_{3} \mathbf{S}_{4}$ & 1.54 & 2.27 & 2.72 & 1.98 & 2.13 \\
\hline $\mathbf{P}_{3} \mathbf{S}_{5}$ & 1.47 & 2.16 & 2.66 & 1.93 & 2.06 \\
\hline Mean & 1.45 & 2.10 & 2.67 & 1.91 & \\
\hline S at P SEd & 0.0466 & 0.0041 & 0.0033 & 0.0226 & \\
\hline $\mathrm{CD}(\mathrm{P}=0.05)$ & 0.0961 & 0.0085 & 0.0069 & 0.0466 & \\
\hline
\end{tabular}

$\mathrm{P}_{1} \quad 0 \%$ Phosphorus $\quad \mathrm{P}_{3} \quad 100 \%$ Phosphorus

$\mathrm{P}_{2} \quad 50 \%$ Phosphorus $\quad \mathrm{S}_{1} \quad$ No seed treatment

$\mathrm{S}_{2} \quad$ JumpStart $10 \mathrm{E} 4(0.097 \mathrm{~g} / \mathrm{kg}$ of seed $)$
$\mathrm{S}_{3} \quad$ JumpStart 10E5 $(0.966 \mathrm{~g} / \mathrm{kg}$ of seed $)$

$\mathrm{S}_{4} \quad$ JumpStart 10E6 $(9.662 \mathrm{~g} / \mathrm{kg}$ of seed $)$

$\mathrm{S}_{5} \quad \operatorname{Azophos}(20 \mathrm{~g} / \mathrm{kg}$ of seed $)$

Table.2 Effect of P levels and Penicillium bilaii inoculants on leaf carbohydrate content $\left(\mathrm{mg} \mathrm{g}^{-1}\right)$ at different growth stages of rice

\begin{tabular}{|c|c|c|c|c|c|}
\hline Treatments & $\begin{array}{c}\text { AT } \\
(40 \text { DAS })\end{array}$ & $\begin{array}{c}\text { PI } \\
(55 \text { DAS })\end{array}$ & $\begin{array}{c}\text { F } \\
(85 \text { DAS })\end{array}$ & $\begin{array}{c}\text { GF } \\
(105 \text { DAS })\end{array}$ & Mean \\
\hline $\mathbf{P}_{1} \mathbf{S}_{1}$ & 25.30 & 42.01 & 52.04 & 40.21 & 39.89 \\
\hline $\mathbf{P}_{1} \mathbf{S}_{2}$ & 37.10 & 52.34 & 60.23 & 48.31 & 49.50 \\
\hline $\mathbf{P}_{1} \mathbf{S}_{3}$ & 42.50 & 57.19 & 67.32 & 53.64 & 55.16 \\
\hline $\mathbf{P}_{1} \mathbf{S}_{4}$ & 33.58 & 48.03 & 58.02 & 45.03 & 46.17 \\
\hline $\mathbf{P}_{1} \mathbf{S}_{5}$ & 30.20 & 42.25 & 56.12 & 43.12 & 42.92 \\
\hline $\mathbf{P}_{2} \mathbf{S}_{1}$ & 31.70 & 48.43 & 61.39 & 45.07 & 46.65 \\
\hline $\mathbf{P}_{2} \mathbf{S}_{2}$ & 44.24 & 60.12 & 71.33 & 57.43 & $\mathbf{5 8 . 2 8}$ \\
\hline $\mathbf{P}_{2} \mathbf{S}_{3}$ & 53.57 & 68.46 & 78.04 & 64.24 & 66.08 \\
\hline $\mathbf{P}_{2} \mathbf{S}_{4}$ & 36.21 & 56.26 & 65.21 & 53.67 & 52.84 \\
\hline $\mathbf{P}_{2} \mathbf{S}_{5}$ & 34.78 & 52.32 & 63.54 & 48.10 & 49.69 \\
\hline $\mathbf{P}_{3} \mathbf{S}_{1}$ & 38.23 & 54.05 & 68.56 & 52.09 & $\mathbf{5 3 . 2 3}$ \\
\hline $\mathbf{P}_{3} \mathbf{S}_{2}$ & 52.05 & 66.45 & 78.21 & 64.25 & 65.24 \\
\hline $\mathbf{P}_{\mathbf{3}} \mathbf{S}_{\mathbf{3}}$ & 62.36 & 74.65 & 82.06 & 73.69 & 73.19 \\
\hline $\mathbf{P}_{3} \mathbf{S}_{4}$ & 46.02 & 62.06 & 73.42 & 60.26 & 60.44 \\
\hline $\mathbf{P}_{3} \mathbf{S}_{5}$ & 41.25 & 58.40 & 70.29 & 57.44 & 56.85 \\
\hline Mean & 40.61 & 56.20 & 67.05 & 53.77 & \\
\hline $\mathrm{S}$ at P SEd & 0.131 & 0.123 & 0.110 & 0.118 & \\
\hline $\mathrm{CD}(\mathrm{P}=\mathbf{0 . 0 5})$ & 0.271 & 0.254 & 0.227 & 0.243 & \\
\hline
\end{tabular}

$\mathrm{P}_{1} \quad 0 \%$ Phosphorus $\quad \mathrm{P}_{3} \quad 100 \%$ Phosphorus

$\mathrm{P}_{2} \quad 50 \%$ Phosphorus $\quad \mathrm{S}_{1} \quad$ No seed treatment

$\mathrm{S}_{2} \quad$ JumpStart 10E4 $(0.097 \mathrm{~g} / \mathrm{kg}$ of seed $)$
$\mathrm{S}_{3} \quad$ JumpStart 10E5 $(0.966 \mathrm{~g} / \mathrm{kg}$ of seed $)$

$\mathrm{S}_{4} \quad$ JumpStart 10E6 $(9.662 \mathrm{~g} / \mathrm{kg}$ of seed $)$

$\mathrm{S}_{5} \quad$ Azophos $(20 \mathrm{~g} / \mathrm{kg}$ of seed $)$ 
Table.3 Effect of P levels and Penicillium bilaii inoculants on acid phosphatase activity ( $\mu \mathrm{mol}$ of $\mathrm{pNPP} \mathrm{g}^{-1} \mathrm{~min}^{-1}$ ) at different growth stages of rice

\begin{tabular}{|c|c|c|c|c|c|}
\hline Treatments & $\begin{array}{c}\text { AT } \\
\text { (40 DAS) }\end{array}$ & $\begin{array}{c}\text { PI } \\
\text { (55 DAS) }\end{array}$ & $\begin{array}{c}F \\
(85 \text { DAS })\end{array}$ & $\begin{array}{c}\text { GF } \\
(105 \text { DAS })\end{array}$ & Mean \\
\hline $\mathbf{P}_{1} \mathbf{S}_{1}$ & 0.081 & 0.131 & 0.146 & 0.117 & 0.119 \\
\hline $\mathbf{P}_{1} \mathbf{S}_{2}$ & 0.055 & 0.064 & 0.084 & 0.061 & 0.066 \\
\hline $\mathbf{P}_{1} \mathbf{S}_{3}$ & 0.041 & 0.052 & 0.070 & 0.054 & 0.054 \\
\hline $\mathbf{P}_{1} \mathbf{S}_{4}$ & 0.060 & 0.097 & 0.096 & 0.083 & 0.084 \\
\hline $\mathbf{P}_{1} \mathbf{S}_{5}$ & 0.074 & 0.104 & 0.125 & 0.102 & 0.101 \\
\hline $\mathbf{P}_{2} \mathbf{S}_{1}$ & 0.068 & 0.114 & 0.132 & 0.106 & 0.105 \\
\hline $\mathbf{P}_{2} \mathbf{S}_{2}$ & 0.047 & 0.051 & 0.063 & 0.045 & 0.052 \\
\hline $\mathbf{P}_{2} \mathbf{S}_{3}$ & 0.036 & 0.042 & 0.048 & 0.039 & 0.041 \\
\hline $\mathbf{P}_{2} \mathbf{S}_{4}$ & 0.053 & 0.063 & 0.089 & 0.053 & 0.065 \\
\hline $\mathbf{P}_{2} \mathbf{S}_{5}$ & 0.061 & 0.082 & 0.103 & 0.087 & 0.083 \\
\hline $\mathbf{P}_{3} \mathbf{S}_{1}$ & 0.045 & 0.091 & 0.115 & 0.082 & 0.083 \\
\hline $\mathbf{P}_{3} \mathbf{S}_{2}$ & 0.031 & 0.046 & 0.058 & 0.038 & 0.043 \\
\hline $\mathbf{P}_{3} \mathbf{S}_{3}$ & 0.024 & 0.028 & 0.022 & 0.027 & 0.025 \\
\hline $\mathbf{P}_{3} \mathbf{S}_{4}$ & 0.033 & 0.051 & 0.074 & 0.041 & 0.050 \\
\hline $\mathbf{P}_{3} \mathbf{S}_{5}$ & 0.037 & 0.055 & 0.095 & 0.062 & 0.062 \\
\hline Mean & 0.050 & 0.071 & 0.088 & 0.066 & 0.069 \\
\hline$S$ at $P$ SEd & 0.00975 & 0.00076 & 0.00066 & 0.00045 & \\
\hline CD $(P=0.05)$ & 0.02013 & 0.00156 & 0.00136 & 0.00092 & \\
\hline
\end{tabular}

$\begin{array}{llllll}\mathrm{P}_{1} & 0 \% \text { Phosphorus } & \mathrm{P}_{3} & 100 \% \text { Phosphorus } & \mathrm{S}_{3} & \text { JumpStart 10E5 }(0.966 \mathrm{~g} / \mathrm{kg} \text { of seed })\end{array}$

$\mathrm{P}_{2} \quad 50 \%$ Phosphorus $\quad \mathrm{S}_{1} \quad$ No seed treatment $\quad \mathrm{S}_{4} \quad$ JumpStart 10E6 (9.662 g/kg of seed)

$\mathrm{S}_{2} \quad$ JumpStart 10E4 (0.097 g/kg of seed) $\quad \mathrm{S}_{5} \quad$ Azophos $(20 \mathrm{~g} / \mathrm{kg}$ of seed $)$

Table.4 Effect of P levels and Penicillium bilaii inoculants on ATPase enzyme activity $\left(\mu \mathrm{g}\right.$ of $\left.\mathrm{Pi}^{-1} \mathrm{~h}^{-1}\right)$ at different growth stages of rice

\begin{tabular}{|c|c|c|c|c|c|}
\hline Treatments & $\begin{array}{c}\text { AT } \\
\text { (40 DAS) } \\
\end{array}$ & $\begin{array}{c}\text { PI } \\
\text { (55 DAS) }\end{array}$ & $\begin{array}{c}F \\
\text { (85 DAS) }\end{array}$ & $\begin{array}{c}\text { GF } \\
\text { (105 DAS) }\end{array}$ & Mean \\
\hline $\mathbf{P}_{1} \mathbf{S}_{1}$ & 21.41 & 33.22 & 57.48 & 26.85 & 34.74 \\
\hline $\mathbf{P}_{1} \mathbf{S}_{2}$ & 17.47 & 28.16 & 52.66 & 23.51 & 30.45 \\
\hline $\mathbf{P}_{1} \mathbf{S}_{3}$ & 13.39 & 25.62 & 49.86 & 18.55 & 26.86 \\
\hline $\mathbf{P}_{1} \mathbf{S}_{4}$ & 18.27 & 30.73 & 54.59 & 21.84 & 31.36 \\
\hline $\mathbf{P}_{1} \mathbf{S}_{5}$ & 20.17 & 31.27 & 56.15 & 25.07 & 33.17 \\
\hline $\mathbf{P}_{2} \mathbf{S}_{1}$ & 19.04 & 30.92 & 54.21 & 24.68 & 32.21 \\
\hline $\mathbf{P}_{2} \mathbf{S}_{2}$ & 15.54 & 24.80 & 43.34 & 19.37 & 25.76 \\
\hline $\mathbf{P}_{2} \mathbf{S}_{3}$ & 10.71 & 19.44 & 37.29 & 14.78 & 20.56 \\
\hline $\mathbf{P}_{2} \mathbf{S}_{4}$ & 16.48 & 26.46 & 48.47 & 20.47 & 27.97 \\
\hline $\mathbf{P}_{2} \mathbf{S}_{5}$ & 18.48 & 28.52 & 53.94 & 21.52 & 30.62 \\
\hline $\mathbf{P}_{3} \mathbf{S}_{1}$ & 17.53 & 27.49 & 49.74 & 20.24 & 28.75 \\
\hline $\mathbf{P}_{3} \mathbf{S}_{2}$ & 12.57 & 19.66 & 35.35 & 16.48 & 21.02 \\
\hline $\mathbf{P}_{3} \mathbf{S}_{3}$ & 8.38 & 15.63 & 29.37 & 12.67 & 16.51 \\
\hline $\mathbf{P}_{3} \mathbf{S}_{4}$ & 13.85 & 22.15 & 40.91 & 18.39 & 23.83 \\
\hline $\mathbf{P}_{3} \mathbf{S}_{5}$ & 15.54 & 26.44 & 46.09 & 19.69 & 26.94 \\
\hline Mean & 15.92 & 26.03 & 47.30 & 20.27 & 27.38 \\
\hline$S$ at $P$ SEd & 0.946 & 1.116 & 1.594 & 1.005 & \\
\hline $\mathrm{CD}(\mathbf{P}=0.05)$ & 1.953 & 2.302 & 3.289 & 2.075 & \\
\hline
\end{tabular}

$\mathrm{P}_{1} \quad 0 \%$ Phosphorus $\quad \mathrm{P}_{3} \quad 100 \%$ Phosphorus

$\mathrm{P}_{2} \quad 50 \%$ Phosphorus $\quad \mathrm{S}_{1} \quad$ No seed treatment

$\mathrm{S}_{2} \quad$ JumpStart 10E4 $(0.097 \mathrm{~g} / \mathrm{kg}$ of seed)
$\mathrm{S}_{3} \quad$ JumpStart 10E5 $(0.966 \mathrm{~g} / \mathrm{kg}$ of seed $)$

$\mathrm{S}_{4} \quad$ JumpStart 10E6 $(9.662 \mathrm{~g} / \mathrm{kg}$ of seed)

$\mathrm{S}_{5} \quad$ Azophos $(20 \mathrm{~g} / \mathrm{kg}$ of seed $)$ 
Table.5 Effect of P levels and Penicillium bilaii inoculants on phosphorus uptake $\left(\mathrm{kg} \mathrm{ha}^{-1}\right)$ at different growth stages of rice

\begin{tabular}{|c|c|c|c|c|c|}
\hline Treatments & $\begin{array}{c}\text { AT } \\
\text { (40 DAS) }\end{array}$ & $\begin{array}{c}\text { PI } \\
\text { (55 DAS) }\end{array}$ & $\begin{array}{c}F \\
(85 \text { DAS })\end{array}$ & $\begin{array}{c}\text { GF } \\
(105 \text { DAS })\end{array}$ & Mean \\
\hline $\mathbf{P}_{1} \mathbf{S}_{1}$ & 5.91 & 21.67 & 38.99 & 25.58 & 23.04 \\
\hline $\mathbf{P}_{1} \mathbf{S}_{2}$ & 11.78 & 36.16 & 68.20 & 40.35 & 39.12 \\
\hline $\mathbf{P}_{1} \mathbf{S}_{3}$ & 16.27 & 42.50 & 75.33 & 48.20 & 45.58 \\
\hline $\mathbf{P}_{1} \mathbf{S}_{4}$ & 8.55 & 30.27 & 58.13 & 36.56 & 33.38 \\
\hline $\mathbf{P}_{1} \mathbf{S}_{5}$ & 6.20 & 25.46 & 46.59 & 32.35 & 27.65 \\
\hline $\mathbf{P}_{2} \mathbf{S}_{1}$ & 10.53 & 27.71 & 49.24 & 38.16 & 31.41 \\
\hline $\mathbf{P}_{2} \mathbf{S}_{2}$ & 17.30 & 46.68 & 78.67 & 47.67 & 47.58 \\
\hline $\mathbf{P}_{2} \mathbf{S}_{3}$ & 24.74 & 58.88 & 84.08 & 53.15 & 55.21 \\
\hline $\mathbf{P}_{2} \mathbf{S}_{4}$ & 11.74 & 38.75 & 65.18 & 41.78 & 39.36 \\
\hline $\mathbf{P}_{2} \mathbf{S}_{5}$ & 9.84 & 34.17 & 58.43 & 38.73 & 35.29 \\
\hline $\mathbf{P}_{3} \mathbf{S}_{1}$ & 12.01 & 39.61 & 65.86 & 45.92 & 40.85 \\
\hline $\mathbf{P}_{3} \mathbf{S}_{2}$ & 23.43 & 52.40 & 86.70 & 54.49 & 54.26 \\
\hline $\mathbf{P}_{3} \mathbf{S}_{3}$ & 34.75 & 65.85 & 92.91 & 67.96 & 65.37 \\
\hline $\mathbf{P}_{3} \mathbf{S}_{4}$ & 17.47 & 44.67 & 77.85 & 48.45 & 47.11 \\
\hline $\mathbf{P}_{3} \mathbf{S}_{5}$ & 14.64 & 40.45 & 68.57 & 43.41 & 41.77 \\
\hline Mean & 15.01 & 40.35 & 67.65 & 44.18 & \\
\hline$S$ at $P$ SEd & 0.128 & 0.162 & 0.218 & 0.128 & \\
\hline CD $(P=0.05)$ & 0.264 & 0.334 & 0.450 & 0.264 & \\
\hline
\end{tabular}

$\begin{array}{llllll}\mathrm{P}_{1} & 0 \% \text { Phosphorus } & \mathrm{P}_{3} & 100 \% \text { Phosphorus } & \mathrm{S}_{3} & \text { JumpStart 10E5 }(0.966 \mathrm{~g} / \mathrm{kg} \text { of seed }) \\ \mathrm{P}_{2} & 50 \% \text { Phosphorus } & \mathrm{S}_{1} & \text { No seed treatment } & \mathrm{S}_{4} & \text { JumpStart 10E6 }(9.662 \mathrm{~g} / \mathrm{kg} \text { of seed }) \\ & & \mathrm{S}_{2} & \text { JumpStart 10E4 }(0.097 \mathrm{~g} / \mathrm{kg} \text { of seed }) & \mathrm{S}_{5} & \text { Azophos }(20 \mathrm{~g} / \mathrm{kg} \text { of seed })\end{array}$

The plasma membrane derived from active proteoid roots of P-deficient plants showed a more than two times higher ATPase activity than P-sufficient roots. Ullrich et al., (1984) reported that a decrease in cytoplasmic $\mathrm{pH}$ and membrane depolarization stimulate a plasma membrane $\mathrm{H}+$-ATPase that pumps protons out of the cell to maintain the intracellular $\mathrm{pH}$ and thus provides the proton driving force for $\mathrm{Pi}$ uptake. Organic acids are a common constituent and are effective in releasing soil $\mathrm{P}$ through a number of mechanisms. It includes reduction in rhizosphere $\mathrm{pH}$ that occurs in response to organic anion exudation, wherein $\mathrm{H}^{+}$ions are released as counter ions (Ryan and Angus, 2003).

\section{Phosphorus uptake}

Phosphorus is absorbed mainly during the vegetative growth; therefore most of its absorbed from is re-translocated in fruits and seed during the reproductive stages. Phosphorus uptake at active tillering stage is crucial to rice crop for higher grain yield. In the present study, at active tillering stage, phosphorus uptake was increased in $100 \% \mathrm{P}$ level combined with Penicillium bilaii (JumpStart 10E5) seed treatment than control treatment by more than four times which is $71.5 \%$ higher than control treatments $\left(\mathrm{P}_{1} \mathrm{~S}_{1}\right)$ as shown in (Table 5). This might be due to phosphorus solubilizing fungal inoculation which produced significant amount of organic acids and have enormous potential for increasing available $\mathrm{P}$ to the plant vicinity, simultaneously enhanced $\mathrm{P}$ uptake. The organic acid produced by Penicillium bilaii (Phosphorus Solubilising Fungus) complexes with the metal cations viz., calcium, aluminium, and iron, thereby helping in solubilization of native phosphorus and reduction in phosphorus sorption. Similar to the result of present study phosphorus solubilizing bacteria (Bacillus subtills), Phosphorus solubilizing fungus (Aspergillus awamori) and AM fungus (Glomus fasciculatum) increasing growth, $\mathrm{N}$ and $\mathrm{P}$ 
uptake in green gram (Zaidi and Khan, 2006).

The data on the performance of phosphorus levels revealed a significant positive relation of grain yield with the increased phosphorus application. The highest grain yield $(16.4 \%)$ was recorded in $\mathrm{P}_{3} \mathrm{~S}_{3}(100 \% \mathrm{P}+$ JumpStart 10E4) compared to control treatment $\left(\mathrm{P}_{1} \mathrm{~S}_{1}\right)$ (Fig. 1). Similar to the present results, Xieet al., (2007) reported that application of phosphorus fertilizer increased straw yield $\left(9.4 \mathrm{t} \mathrm{ha}^{-1}\right)$ compared to control treatment $\left(8.7 \mathrm{t} \mathrm{ha}^{-1}\right)$ in rice crop.

The higher levels of dry matter production and grain yield upon fungal inoculation was mainly due to higher enzyme activities in the rhizosphere and better nutrient availability besides the production of the plant growth regulators by PSM. Increase in the grain yield and straw yield of wheat was also observed when inoculated with phosphorus solubilising microorganism (PSM) (Kumar et al., 1999).

In conclusion, application of recommended $\mathrm{P}$ fertilizer $\left(50 \mathrm{~kg} \mathrm{ha}^{-1}\right)$ along with the seed treatment of JumpStart 10E5 (0.966 g/ kg of seed) under machine transplanting system is suggested as a sustainable way for increasing rice yield. PSFs mainly Penicillium bilaiiis very effective for increasing plant available Phosphorus in soil as well as the growth and yield of rice. Therefore, the use of the Penicillium bilaii through bio-inoculants has enormous potential for making use of ever increasing fixed Phosphorus in the soil and natural reserves of phosphate rocks. There is a need to explore Penicillium bilaii with greater efficiency and synergy with other microbes interacting with plants.

\section{References}

Adesemoye, A.O. and J.W. Kloepper. 2009. Plant-microbes interactions in enhanced fertilizer-use efficiency. Appl. Microbio. Biotech., 85: 1-12.

Cakmakci R., F. Donmez, A. Aydın and F. Şahin.2006. Growth promotion of plants by plant growth-promoting rhizobacteria under greenhouse and two different field soil conditions. Soil Biol. Biochem., 38:1482- 1487.

Degroot, C. C., R.V.D. Boogaard, L. F. M. Marcelis, J. Harbinson and $\mathrm{H}$ Lambers.2003. Contrasting effects of $\mathrm{N}$ and $\mathrm{P}$ deprivation on the regulation of photosynthesis in tomato plants in relation to feedback limitation. J. Exp. Bot., 54: 1957-1967.

Dobermann, A., K.G. Cassman, C.P. Mamariland J.E. Sheehy. 1998 Management of phosphorus, potassium and sulfur in intensive irrigated lowland rice. Field Crop Res., 56: 113- 138

Fales, F.W. 1951. The assimilation and degradation of carbohydrate by yeast cells. J. Biol. Chem., 193: 113-124.

Gomez, K.A and A.A.Gomez. 1984. Statistical procedures for Agricultural Research. An IRRI book, Wiley Inter Science publication, John Wile and Sons, New York, USA.pp 680.

Hartemink, A.E., M. Johnston, J.N. Sullivan and S. Poloma. 2000. Nitrogen use efficiency of taro and sweet potato in the humid lowlands of Papua New Guinea. Agic. Ecos. Environ., 79: 271-280.

Hiscox, J.D. and G.F. Israelstam. 1979. A method for the extraction of chlorophyll from leaf tissue without maceration. Can. J. Bot., 57: 1332-1334.

Hong Shen, J.Chen and Z.Wang.2006. Root plasma membrane H+-ATPase is involved in the adaptation of soyabean to phosphorus starvation. J. Exp. Bot., 57: 1353-1362.

Hooley, 1984.Gibberellic acid controls the secretion of acid phosphatase in aleurone layers and

isolatedaleurone protoplasts of Avenafatua. $J$. Exp. Bot., 35: 822-828

IRRI (International Rice Research Institute), 1997. Annual report for 1972. Los Banos, Philippnes

Jeong, H. L., I. Chung, S. S. Ryu, M. R. Park and S. J. Yun. 2003. Differential responses of rice acid phosphatase 
activities and isoforms to phosphorus deprivation. J. Biochem. Mol. Biol., 36: 597-602.

Kim, K.Y., D. Jordan and G.A.McDonald.1998. Enterobacteragglomerans, phosphate solubilizing bacteria and microbial activity in soil: effect of carbon sources. Soil Biol. Biochem., 89: 995-1003

Kumar, V., S.S. Punia, K. Lakshminarayana and N.Narula. 1999. Effect of phosphate solubilizing analogue resistant mutants of Azotobacter chroococcum on sorghum. Ind. J. Agric Sci., 69: 198-200.

Mehrvarz, S. and M.R. Chaichi.2008. Effect of Phosphate Solubilizing Microorganisms and Phosphorus Chemical Fertilizer on Forage and Grain Quality of Barely (Hordeum vulgare L.). Am.-Eur. J. Agric. Environ. Sci., 3(6):

855-860.

Muthaiya, S. 2010.Physiological effects of phosphate inoculants (JumpStart) in maize (Zea mays L.). M.Sc. (Agri.) Thesis. Tamil Nadu Agricultural University, Coimbatore.

Perderson, P.L. and E. Carafoli.1987. Ion motive ATPase. I. Ubiquity, properties and significance to cell function. Trends Biochem. Sci., 12: 146-150.

Prasanna. R. 2013.Physiological impact of phosphate solubilisinginoculants (JumpStart) in rice. M.Sc (Agri) thesis. Tamil Nadu Agricultural University, Coimbatore.

Ramezan, Ali.,N.Khavari, N. Farzaneh and T. Cobra. 2008. Diverse responses of tomato to $\mathrm{N}$ and $\mathrm{P}$ deficiency. Inter. J. Agric. Biol., 1560-8530
Rasipour, L. and N.A. Asgharzadeh. 2007. Then interaction between the PSB and Bradirhizobium japanicum growth factors, tumor size and uptake of some nutrients in soybean. Agric. Natural Res. Sci., 11(5): 40-63.

Ryan, M.H and J.F. Angus.2003. Arbuscular mycorrhizae in wheat and field pea crops on a low P soil: increased Zn-uptake but no increase in P-uptake or yield. Plant Soil, 250:225-239.

Rychter, A.M. and D.D. Randall. 1994. The effect of phosphate deficiency on carbohydrate metabolism in bean roots. Physiol. Plantarum, 91: 383-388

Ullrich, C.I., A.J. Novacky, E.Fisher and U. Liittge. 1984. Relationship between energy dependent phosphate uptake and the electrical membrane-potential in (Lemna gibba L). J. Plant Physiol., 67: 797-801.

Umbreit, W.W., R.H. Burris and J.F. Stauffer. 1964. Carbon dioxide and bicarbonate. In: Umbreit WW, Burris RH, Stauffer JF (Eds.). Manometric techniques. 4th edn. Burgess Publishers. 18-27

Wang, S., H. Wu., J.Qiao, L. Ma., J. Liu.,Y. Xia and X. Gao. 2009. Molecular mechanism of plant growth promotion and induced systemic resistance to tobacco mosaic virus by Bacillus sp. Biotechnol., 19(10): 1250-1258

Xie, W., G. Weng and Q. Zhang. 2007. Potentical production simulation and optimal nutrient management of two hybrid rice varieties in Jinhua, Zhejiang Province. J. Zhejiang Univ. Sci., 8(7): 486- 492.

\section{How to cite this article:}

Geethalakshmi, M., V. Ravichandran, P. Boominathan and Jeyakumar, P. 2017. Response of Phosphate Solubilising Inoculants (Jumpstart) on Biochemistry and Yield of Rice (Oryza sativa L.). Int.J.Curr.Microbiol.App.Sci. 6(6): 1529-1537. doi: https://doi.org/10.20546/ijcmas.2017.606.180 